I N S T I T U T O

$\mathrm{DE}$

M E D I C I N A

T R O P I C A L

$\mathrm{DE}$

S ÃO PAULO

JOURNAL OF THE SÃO PAULO INSTITUTE OF TROPICAL MEDICINE

'Universidade Federal de São João del-Rei, Divinópolis, Minas Gerais, Brazil

2Universidade de São Paulo, Instituto de Medicina Tropical de São Paulo, São Paulo, São Paulo, Brazil

${ }^{3}$ Universidade Federal de Minas Gerais, Hospital das Clínicas, Belo Horizonte, Minas Gerais, Brazil

Correspondence to: Nayara Ragi Baldoni Universidade Federal de São João del-Rei, R. Sebastião Gonçalves Coelho, 400, Chanadour, CEP 35501-296, Divinópolis, MG, Brazil

E-mail: nrbaldoni@gmail.com

Received: 16 January 2021

Accepted: 8 May 2021

\section{Quality of life in patients with Chagas disease and the instrument used: an integrative review}

\author{
Nayara Ragi Baldoni ${ }^{(1}$, Nayara Dornela Quintino', Geisa Cristina Silva \\ Alves $^{1}$, Claudia Di Lorenzo Oliveira ${ }^{1}$, Ester Cerdeira Sabino ${ }^{2}$, Antonio Luiz \\ Pinho Ribeiro ${ }^{(13}$, Clareci Silva Cardoso ${ }^{(1}$
}

\section{ABSTRACT}

Chagas disease $(\mathrm{CD})$ is a neglected tropical highly morbid disease that can have a negative impact on the quality of life (QoL). The purpose of this study was to conduct an integrative review to analyze the QoL of patients with $\mathrm{CD}$ in the chronic phase of the disease, as well as the instruments used and the effect of different interventions. The review was carried out based on the criteria and recommendations of the Preferred Reporting Items for Systematic Reviews and Meta-Analyzes guideline (PRISMA) using the PubMed, Scopus, Web of Science and Science Direct databases. An analysis of the reference list of the included articles was also carried out. Publications in all languages have been included. Two independent reviewers selected the eligible articles and extracted the data. A total of 1,479 articles were identified, and after applying the inclusion criteria 18 articles were included. Four different instruments were used to assess QoL and the most used was the Minnesota Living with Heart Failure Questionnaire (MLWHFQ) [33.3\% ( $\mathrm{n}=6)$ ]. Investigations involving intervention showed a positive impact on the patients' QoL, and the Environment domain had the lowest score. Heterogeneity of instruments and lack of methodology standardization for assessing QoL was observed. QoL proved to be an important indicator for the planning and monitoring of patients with $\mathrm{CD}$, however it is suggested that the instruments for its assessment should be the ones recommended by the validation studies. This process will allow the comparison of data between investigations.

KEYWORDS: Chagas disease. Quality of life. Neglected diseases.

\section{INTRODUCTION}

Chagas disease (CD) is a tropical disease caused by the protozoan Trypanosoma $c r u z i^{1}$. It is estimated that six to seven million people have CD worldwide, and they are located mainly in Latin American countries, with an emphasis on Argentina, Brazil, Mexico and Bolivia ${ }^{1-4}$. The incidence of CD is falling, with an incidence rate of $1.85 \%$ person-year, but we have a significant number of people living with the disease in the chronic form due to reduced mortality and increased survival, as a result of better knowledge of the natural history of the disease and improvement in clinical and surgical care ${ }^{5,6}$.

$\mathrm{CD}$ in the acute phase, is often unidentified and can progress to the chronic phase, also called the indeterminate form, in which the majority of patients are asymptomatic. The other chronic manifestations of CD are cardiac, digestive or both. Cardiac manifestation affects $20-30 \%$ of patients with chronic CD, and may present cardiomyopathy and congestive heart failure $(\mathrm{HF})^{7,8}$. The digestive 
manifestation involve the development of megaesophagus and megacolon ${ }^{9}$.

These complications may cause a decrease in the perception of quality of life (QoL) in individuals affected by the disease ${ }^{10,11}$. The QoL indicator is an important marker for the organization of health care in addition to the planning of public policies and the allocation of resources ${ }^{12,13}$. Because $\mathrm{CD}$ is a neglected disease in which the majority of patients attend public health services, there are great challenges in providing comprehensive health care and strengthening epidemiological and entomological surveillance actions ${ }^{14}$.

Therefore, studies on QoL in individuals with $\mathrm{CD}$ need to be better explored and understood in order to develop effective health intervention strategies ${ }^{15}$. However, evaluating the QoL indicator is not simple, due to the multidimensional characteristic of this construct, defined as "the individual's perception of their position in life in the context of the culture and the value of a system in which they live and in relation to their goals, expectations, patterns, and concerns" $" 16$.

Thus, knowing the main aspects related to a worse QoL among individuals with $\mathrm{CD}$ will allow more specific interventions to improve health care. Thus, the aim of this study is to conduct an integrative review to analyze the QoL of patients with CD in the chronic phase, as well the instruments used for this analysis and the effect of different interventions.

\section{MATERIALS AND METHODS}

The present study is an integrative review following the Preferred Reporting Items for Systematic Reviews and Meta-Analyzes Guideline - The PRISMA Statement ${ }^{17}$. The review protocol was registered under the number CRD42020148296. The study's hypothesis is that patients with chronic CD have a lower QoL. Thus, the question that guided this investigation was: What is the quality of life profile of patients with chronic Chagas disease? From the guiding question, the "PCO" was established: "P" (problem situation): Individuals with Chagas disease; "C" (condition): Chronic Chagas disease; "O" (Outcome): Quality of life. Articles that assessed the QoL of adult individuals with $\mathrm{CD}$ in the chronic phase, in all languages and without time limit, were considered eligible. Articles whose participants were in the acute phase of the disease, review articles, protocols, editorials, letters to the editor, news, comments, dissertations, and theses were excluded.

The PubMed, Scopus, Web of Science and Science Direct databases were used to analyze studies published until 02/09/2019. There was no restriction on the start date of the collection, since the objective was to retrieve the maximum number of articles, regardless of the year of publication. In all databases, searches were performed in the advanced mode. The Boolean operators "OR" and "AND" were used to relate the words or group of words in the process of elaborating the search (Supplementary Table S1).The data obtained from the databases were exported to the Rayyan QCRI virtual platform, whose objective was to facilitate the selection of eligible articles ${ }^{18}$. In the first reading, titles and abstracts were read by two researchers (NRB and NDQ) independently, to avoid bias in the selection. In case of disagreement between the two reviewers, a third researcher (CSC) evaluated, and by consensus, the final decision was made on whether or not to include the article.

In order to detect other publications of relevance which may not have been identified by the search strategy, a new search was performed using the bibliographic references of the selected articles. The restricted access studies, which were not fully available in the databases, were requested in a public library and/or formally to the corresponding authors via e-mail. Articles that met the inclusion criteria were read in full and information about the authors, country, study design, number of patients, morbidity of the clinical form of $\mathrm{CD}$, and instrument used to assess QoL was collected.

\section{QoL instruments}

Table 1 shows the instruments that were used to assess QOL in the selected studies with their respective domains and scores. Four different QOL assessment instruments were identified, namely: MLWHFQ, SF-36, WHOQoLBref and KCCQ. Among these instruments, two are considered specific for individuals with HF (MLWHFQ and KCCQ) and two are generic (SF-36 and WHOQoLBref). The domains present in the instruments ranged in number from three to eight. The MLWHFQ is an instrument composed of 21 questions about the limitations often associated with HF. The answer scale for each question varies from 0 (zero) to five, where 0 represents no limitations and 5 represents maximum limitation ${ }^{19}$.

As for the SF-36 instrument, it has 36 questions that are grouped into eight domains and presents a final score for each domain ranging from 0 (zero) to 100 , where zero identifies the worst general health status and 100 the best ${ }^{20}$. The WHOQoL-Bref has 26 questions, two of which are generic and the other 24 are divided into four domains: Physical, Psychological, Social Relations and Environment. Responses are scored on a five point Likert scale ${ }^{21}$. Finally, the KCCQ instrument consists of 15 questions, 
Table 1 - Instruments used to assess the quality of life in selected studies, their assessed domains and respective scores.

\begin{tabular}{|c|c|c|}
\hline QoL Scale & Domains & Score \\
\hline MLWHFQ & $\begin{array}{l}\text { 1. Physical } \\
\text { 2. Psychological } \\
\text { 3. General }\end{array}$ & $\begin{array}{l}0 \text { to } 105: \text { a lower } \\
\text { score represents } \\
\text { a better QoL }\end{array}$ \\
\hline SF-36 & $\begin{array}{l}\text { 1. Functional capacity } \\
\text { 2. Physical aspects } \\
\text { 3. Pain } \\
\text { 4. General State of Health } \\
\text { 5. Vitality } \\
\text { 6. Social aspects } \\
\text { 7. Emotional aspects } \\
\text { 8. Mental Health }\end{array}$ & $\begin{array}{l}0 \text { to } 100 \text { : the } \\
\text { higher score, the } \\
\text { better the QoL }\end{array}$ \\
\hline WHOQoL-Bref & $\begin{array}{l}\text { 1. Physical } \\
\text { 2. Psychological } \\
\text { 3. Social Relations } \\
\text { 4. Environment }\end{array}$ & $\begin{array}{c}0 \text { to } 100: \text { the } \\
\text { higher the score, } \\
\text { the better the } \\
\text { QoL }\end{array}$ \\
\hline $\mathrm{KCCQ}$ & $\begin{array}{l}\text { 1. Physical limitation } \\
\text { 2. Symptoms } \\
\text { 3. Social limitation } \\
\text { 4. Self-efficacy } \\
\text { 5. Quality of life }\end{array}$ & $\begin{array}{c}0 \text { to } 100 \text { : the } \\
\text { higher the score, } \\
\text { the better the } \\
\text { QoL }\end{array}$ \\
\hline
\end{tabular}

MLWHFQ = Minnesota Living With Heart Failure Questionnaire; SF-36 = Short-Form; WHOQoL-Bref = World Health Organization Quality of Life; KCCQ = Kansas City Cardiomyopathy Questionnaire; QoL = Quality of Life.

with 23 items, organized into five domains ${ }^{22}$. All of these instruments provide a global assessment, without reference to a cutoff point for better or worse QOL.

\section{Quality assessment and risk of bias}

To assess quality and risk of bias, the Dows and Black tool (1998), developed and validated for randomized and observational studies, was used ${ }^{23}$. This tool has 27 questions, however, for observational studies the instrument was adapted using only 22 questions. The studies were considered to be of low and moderate risk of bias when they did not reach $70 \%$ of the assessed domains. The scale developed by the Oxford Center for EvidenceBased Medicine was used to assess the level of evidence and the degree of recommendation of the included studies. This tool allows the evaluation of each article according to the method used ${ }^{24}$.

\section{Additional analysis}

To analyze whether there was a change in the QoL according to the type of intervention study, the Delta Module (I $\Delta \mathrm{I})$ was calculated, i.e., the difference in the QoL scores between the last assessment and the first ( $\mathrm{I} \Delta \mathrm{I}=$ last - baseline) was recorded.

\section{RESULTS}

A total of 1,479 articles were identified, of which 180 were initially excluded due to duplication. After reading the title and abstract, 22 articles were selected for full reading. After analyzing these articles in full, 17 studies met the criteria for inclusion in the analysis. In addition, all references of these included articles were analyzed $(n=593)$ and after analyzing the references, one additional article was included in the sample, totaling 18 articles (Figure 1).
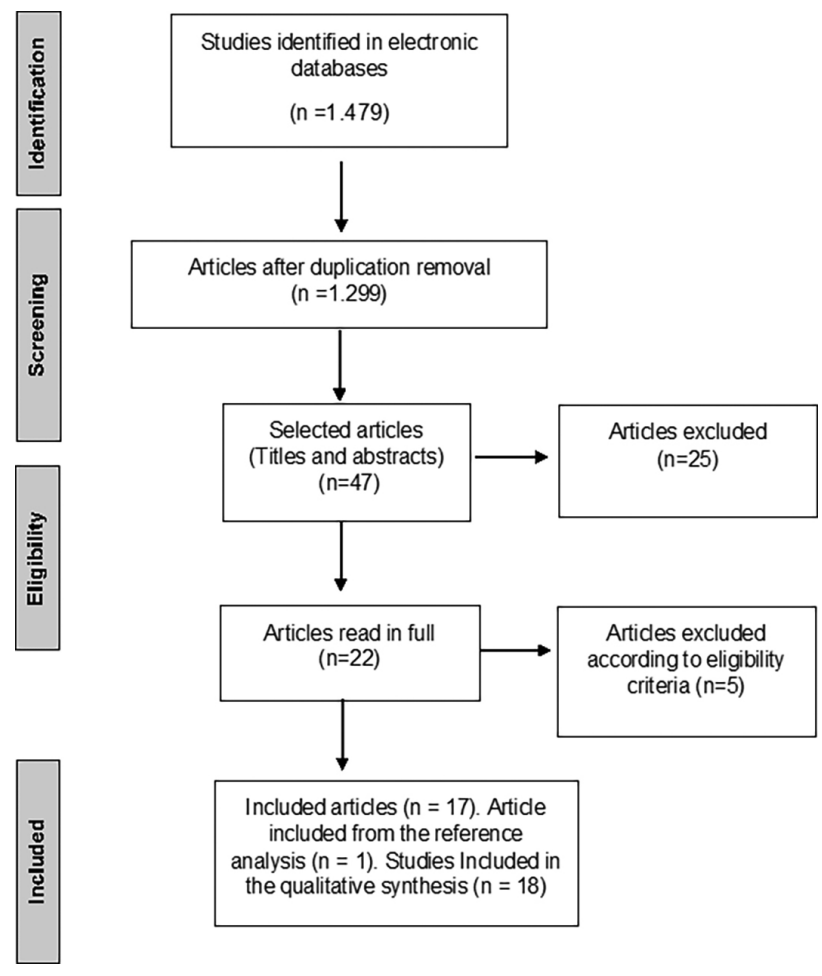

Figure 1 - PRISMA Flowchart.

All articles were reviewed. The publications took place from 2006 to 2019, the majority of which were conducted in Brazil 94.4\% $(n=17)$. The studies were of the observational and intervention type, with 50\% $(\mathrm{n}=9)$ being observational studies. Most of the articles involved patients with Chagas cardiomyopathy with HF. Only two studies stratified the clinical form of $\mathrm{CD}^{11,25}$ (Table 2).

The instrument most used by researchers to assess QoL of patients with $\mathrm{CD}$ was the specific instrument for HF, the Minnesota Living With Heart Failure Questionnaire (MLWHFQ) [33.3\% $(n=6)$ ], followed by two generic instruments, the Short -Form (36) (SF-36) [27.7\% ( $=5)]$ and the World Health Organization Quality of Life (WHOQoL-Bref) $[22.2 \%(\mathrm{n}=4)]^{19,20,21}$. One study used the specific Kansas City Cardiomyopathy Questionnaire (KCCQ) instrument to assess QoL in patients with HF $[5.5 \%(\mathrm{n}=1)]^{22}$. Two studies evaluated QoL with two 


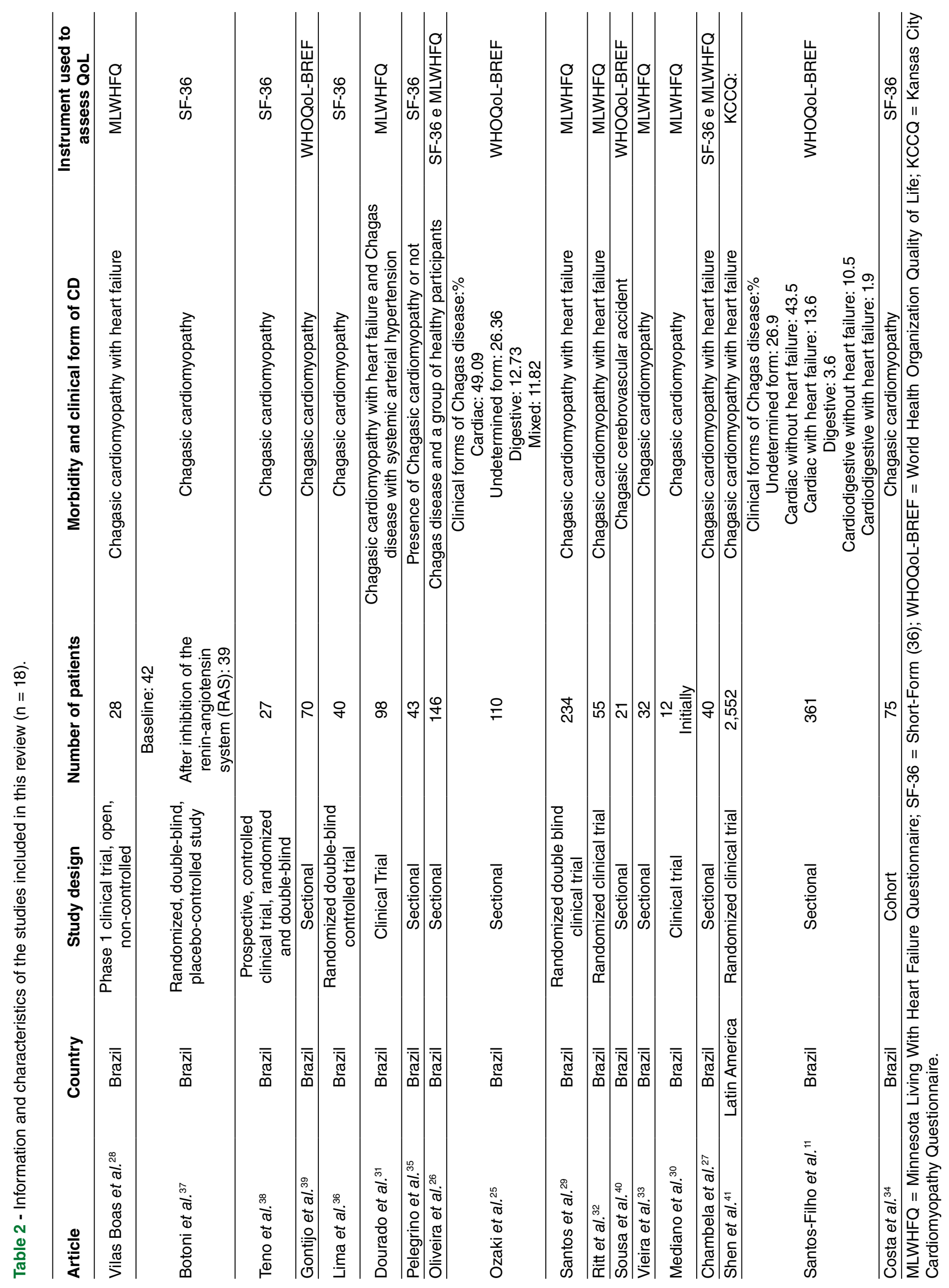


instruments, one being a generic instrument (SF-36) and another specific for HF (MLWHFQ) ${ }^{26,27}$ (Table 2).

Among studies that used the MLWHFQ scale, three were intervention studies and assessed QoL before and after the intervention and all showed an increase in the QoL scores of patients ${ }^{28-30}$. The greatest increase observed was in the study after the intervention with stem cells $(I \Delta I=29.1)$ and after transplantation of autologous cells derived from bone marrow $(\mathrm{I} \Delta \mathrm{I}=24.0)(\text { Table } 3)^{28,29}$.

Regarding the studies that also used the MLWHFQ scale

Table 3 - Effect of interventions on the Quality of Life in patients with Chagas disease, by instrument.

\begin{tabular}{|c|c|c|c|c|c|}
\hline \multirow[b]{2}{*}{ Article } & \multicolumn{4}{|c|}{ Quality of life scores } & \multirow[b]{2}{*}{$\mathbf{I} \Delta \mathbf{I}$} \\
\hline & Intervention & T0 & T1 & T2 & \\
\hline \multicolumn{6}{|c|}{ Minnesota Living with Heart Failure Questionnaire (MLWHFQ) } \\
\hline Vilas Boas et al. ${ }^{28}$ & $\begin{array}{c}\text { Bone } \\
\text { marrow cell } \\
\text { transplantation }\end{array}$ & $\begin{array}{l}\text { Mean (SD) } \\
50.9(11.7)\end{array}$ & $\begin{array}{l}\text { Mean (SD) } \\
21.8(13.4)\end{array}$ & -- & 29.1 \\
\hline \multirow[t]{2}{*}{ Santos et al. ${ }^{29}$} & $\begin{array}{l}\text { Bone marrow- } \\
\text { derived } \\
\text { autologous cell } \\
\text { transplantation }\end{array}$ & $\begin{array}{c}\text { Intervention: Baseline } \\
\text { Median } \\
\text { (Interquartile Range) } \\
46.3(40.9-51.8)\end{array}$ & $\begin{array}{c}\text { Intervention: After } 6 \\
\text { months } \\
\text { Median } \\
\text { (Interquartile Range) } \\
25.3(19.2-31.3)\end{array}$ & $\begin{array}{c}\text { Intervention: After } 12 \\
\text { months } \\
\text { Median } \\
\text { (Interquartile Range) } \\
22.3(16.2-28.5)\end{array}$ & 24.0 \\
\hline & & $\begin{array}{c}\text { Placebo: Baseline } \\
44.5(40.0-49.1)\end{array}$ & $\begin{array}{c}\text { Placebo: } \\
\text { After } 6 \text { months } \\
21.2(16.1-26.3)\end{array}$ & $\begin{array}{c}\text { Placebo: } \\
\text { After } 12 \text { months } \\
22.6(17.1-28.1)\end{array}$ & 21.9 \\
\hline Mediano et al. ${ }^{30}$ & $\begin{array}{c}\text { Exercise } \\
\text { performed } \\
3 \text { times a week, } \\
60 \text { minutes per } \\
\text { session, over a } \\
\text { period of } \\
8 \text { months } \\
\end{array}$ & $\begin{array}{c}\text { Mean (SD) } \\
41(25.4)\end{array}$ & $\begin{array}{l}\text { Mean (SD) } \\
25.0(21.1)\end{array}$ & -- & 16.0 \\
\hline \multicolumn{6}{|c|}{ Short-Form (36) (SF-36) } \\
\hline Botoni et al. ${ }^{37}$ & $\begin{array}{l}\text { Enalapril and } \\
\text { spironolactone. } \\
\text { Patients were } \\
\text { subsequently } \\
\text { randomly } \\
\text { assigned to } \\
\text { receive either } \\
\text { placebo or } \\
\text { carvedilol }\end{array}$ & $\begin{array}{c}\text { Physical capacity: } 65 \\
\text { (40 to } 90) \\
\text { Physical aspect: } 25 \\
\text { (0 to } 75) \\
\text { Pain: } 56.5 \text { (32 to } 72) \\
\text { General health: } 53.5 \\
\text { (32 to } 72) \\
\text { Vitality: } 67.5 \text { (35 to } 75) \\
\text { Social aspect: } 81.3 \\
\text { (62.5 to } 100) \\
\text { Emotional aspect: } 66.6 \\
\text { (0 to 100) } \\
\text { Mental health: } 88 \\
\text { (44 to } 48)\end{array}$ & $\begin{array}{c}\text { Physical capacity: } 80 \\
\text { (50 to } 90) \\
\text { Physical aspect: } 75 \\
\text { ( } 25 \text { to } 100) \\
\text { Pain: } 72 \text { (51 to } 100) \\
\text { General health: } 62 \\
\text { (51 to } 80) \\
\text { Vitality: } 65 \text { (50 to } 90) \\
\text { Social aspect: } 87.5 \\
\text { (50 to } 100) \\
\text { Emotional aspect: } 66.6 \\
\text { (0 to } 100) \\
\text { Mental health: } 76 \\
\text { (52 to } 92)\end{array}$ & & $\begin{array}{r}15.0 \\
50.0 \\
15.5 \\
8.5 \\
2.5 \\
6.2 \\
0 \\
12.0\end{array}$ \\
\hline Teno et al. ${ }^{38}$ & $\begin{array}{l}\text { Ventricular and } \\
\text { atrioventricular } \\
\text { stimulation }\end{array}$ & $\begin{array}{c}\text { Physical capacity: } 68 \\
\text { (19.1) } \\
\text { Overall condition: } 73.9 \\
(17.5) \\
\text { Vitality: } 63.5(20.7)\end{array}$ & $\begin{array}{c}\text { Ventricular stimulation: } \\
\text { Physical capacity: } 71.3 \\
(18.2) \\
\text { General health: } 68.1 \\
(21.8) \\
\text { Vitality: } 64.8(24.6) \\
\\
\text { Atrioventricular } \\
\text { stimulation: } \\
\text { Functional capacity: } 69.3 \\
\text { (20.4) } \\
\text { Overall health: } 69.4 \\
(19.4) \\
\text { Vitality: } 67.6(25.5)\end{array}$ & -- & $\begin{array}{l}1.3 \\
4.5 \\
4.1\end{array}$ \\
\hline
\end{tabular}


but did not assess QoL before and after the intervention, one assessed the QoL of participants with CD and hypertension and another group with CD only; the mean was similar between groups, 41.3 versus $37.7^{31}$. Another intervention survey that has also assessed QoL only at baseline, showed an average of $38^{32}$. In the study of Vieira et al. ${ }^{33}$, it was observed that the QoL scores in patients without heart disease (mean global score: 7.2) were better than those who do not have this morbidity (mean global score: 31.8 ) (Table 4).

With regard to the studies that used the SF-36 scale, one of them was a prospective study and assessed QoL at baseline and after six years, among groups of Chagasic participants with and without cardiovascular adverse events. The results showed that among the domains evaluated, the summary of the mental component is that the lowest QoL median was found in both participants, those who developed adverse events (33) and those who did not (44) ${ }^{34}$. In the study by Pelegrino et al. ${ }^{35}$, eight domains of the instrument were evaluated in people with Chagas cardiomyopathy and people without Chagas cardiomyopathy. Participants without Chagas cardiomyopathy had better QoL scores in all assessed domains (Table 5).

Table 4 - Profile of the quality of life in people with Chagas disease assessed by specific instruments: MLWHFQ and KCCQ.

\begin{tabular}{|c|c|c|c|c|}
\hline \multicolumn{5}{|c|}{ Quality of life } \\
\hline \multirow{3}{*}{ Article } & \multicolumn{4}{|c|}{ Minnesota Living with Heart Failure Questionnaire (MLWHFQ) } \\
\hline & Total & Physical & Psychological & General \\
\hline & \multicolumn{4}{|c|}{ Mean(SD) } \\
\hline \multirow{6}{*}{ Dourado et al. ${ }^{31 *}$} & \multicolumn{4}{|c|}{ Chagas disease with SAH } \\
\hline & $41.3(20.6)$ & NA & NA & NA \\
\hline & \multicolumn{4}{|c|}{ Chagas disease } \\
\hline & $37.7(21.4)$ & NA & NA & NA \\
\hline & Total & Physical & Psychological & General \\
\hline & \multicolumn{4}{|c|}{ Mean(SD) } \\
\hline \multirow{6}{*}{ Oliveira et al. ${ }^{26}$} & \multicolumn{4}{|c|}{ Without Chagas disease } \\
\hline & $0(0-10)$ & NA & NA & NA \\
\hline & \multicolumn{4}{|c|}{ With Chagas disease } \\
\hline & $5(0-14)$ & NA & NA & NA \\
\hline & Total & Physical & Psychological & General \\
\hline & & Mean $(\varsigma$ & & \\
\hline \multirow{3}{*}{ Ritt et al. ${ }^{32 \star}$} & $38(18)$ & NA & NA & NA \\
\hline & Total & Physical & Psychological & General \\
\hline & \multicolumn{4}{|c|}{ Mean (SD) } \\
\hline \multirow{4}{*}{ Vieira et al. ${ }^{33}$} & \multicolumn{4}{|c|}{ With cardiomyopathy } \\
\hline & $31.8(23.2)$ & $12.4(10.5)$ & $7.9(6.8)$ & $11.5(7.2)$ \\
\hline & \multicolumn{4}{|c|}{ Without cardiomyopathy } \\
\hline & $7.2(9.7)$ & $2.4(4.2)$ & $3.4(4.1)$ & $1.4(1.9)$ \\
\hline \multirow{6}{*}{ Chambela et al. ${ }^{27}$} & Total & Physical & Psychological & General \\
\hline & \multicolumn{4}{|c|}{ Mean (SD) } \\
\hline & $30.5(27.7)$ & NA & NA & NA \\
\hline & \multicolumn{4}{|c|}{ Kansas City Cardiomyopathy Questionnaire (KCCQ) } \\
\hline & Total & Physical & Psychological & General \\
\hline & \multicolumn{4}{|c|}{ Median (Q1-Q3) } \\
\hline \multirow{6}{*}{ Shen et al. ${ }^{41 *}$} & \multicolumn{4}{|c|}{ Ischemic cardiomyopathy } \\
\hline & $85(72-94)$ & NA & NA & NA \\
\hline & \multicolumn{4}{|c|}{ Non-Ischemic cardiomyopathy } \\
\hline & $87(74-96)$ & NA & NA & NA \\
\hline & \multicolumn{4}{|c|}{ Chagasic cardiomyopathy } \\
\hline & $82(70-92)$ & NA & NA & NA \\
\hline
\end{tabular}

${ }^{\star}$ Baseline data (cross-sectional analysis) was used. 


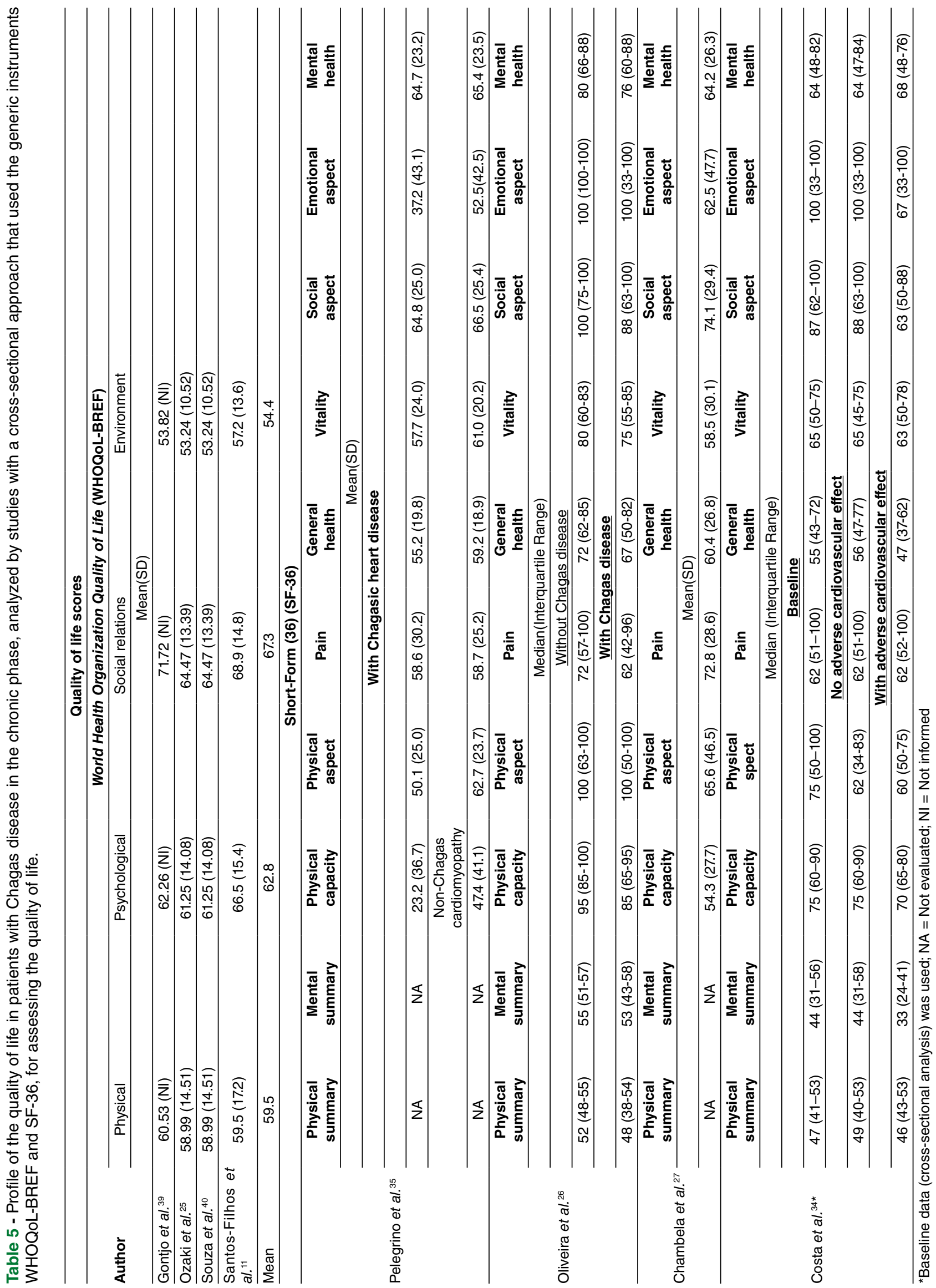


The study by Lima et $a l .^{36}$, has also used the SF-36 butthe results are not described in the table because the authors only present the $\Delta \mathrm{QoL}$ value. The mean and medians were used, however no feedback from the authors was obtained. Another intervention study showed positive results in which there was an increase in QoL in five of the eight domains, mainly in the Physical Aspect domain, in which the median progressed from a score of 25 to 75 $(\text { Table } 3)^{37}$.

Still referring to the SF-36 instrument, an intervention work was carried out in which QoL was assessed at baseline and after two different interventions, with one group undergoing ventricular stimulation and another atrioventricular stimulation. The domains of Functional Capacity and Vitality showed an increase in QoL scores, however for the General State domain, there was a reduction in scores after intervention; at baseline the mean reduced from 73.9 to 68.1 in the ventricular stimulation and to 69.4 in the atrioventicular ${ }^{38}$ (Table 3).

All studies with the WHOQoL-Bref instrument used a sectional study design ${ }^{11,25,39,40}$. When calculating the mean of the Physical, Psychological, Social Relations and Environment domains, the results were 59.5, 62.8, 67.3, and 55.4 , respectively. In other words, the domain related to the environment was the one with the greatest compromise in QoL (Table 5).

A single study used the KCCQ instrument, which like MLWHFQ, is an instrument for assessing QoL specific for HF. In the study by Shen et al. ${ }^{41}$, the QoL of participants with ischemic heart disease, non-ischemic heart disease and Chagasic heart disease were evaluated, the median results were 82,87 and 82, respectively (Table 4). Therefore, participants with non-ischemic heart disease had higher QoL scores.

Finally, the two studies that used two instruments presented the following results. The survey by Oliveira $\mathrm{et} \mathrm{al.}{ }^{26}$ was the only study that assessed the QoL of patients with and without CD. The MLWHFQ evaluation showed an average score of 5 and zero, respectively. Regarding the SF-36 assessment, among the eight domains of the instrument, five showed higher QoL scores in participants without $\mathrm{CD}$. That is, in the two instruments used, patients without Chagas disease had better QoL. The second study which used two instruments, presented QoL correlation data, so an email was sent to the authors requesting the mean and standard deviation of the results, and these data were returned and are presented in Tables 2 and $3^{27}$. After analyzing these instruments, it was observed that there is no superiority between them, however, many dimensions were not evaluated, which hindered a more accurate analysis.

Regarding the quality of the studies evaluated, $55.5 \%$ $(\mathrm{n}=10)$ were considered to have a low or moderate risk of bias. Regarding the level of evidence and degree of recommendation from Oxford, $50 \%(n=9)$ were classified as evidence $2 \mathrm{~b}$, considered consistent studies, in which there is reasonable evidence to support this recommendation, with good standards of reference for decisions. The other half of the studies $(n=9)$ were classified as evidence 2c (research outcomes), which consists of studies with little evidence for the analysis of outcomes, as these are investigations with an observational sectional design.

\section{DISCUSSION}

In view of the main findings of this investigation, it is observed that studies related to QoL in patients with $\mathrm{CD}$ are relatively recent and scarce. Among the instruments used to assess QoL, the most used was MLWHFQ followed by SF-36. From the studies that used the WHOQoL-Bref, it was possible to identify that the Environment domain was the one that influenced the most the QoL in people with CD. A similar result was found in the study by Quintino et al. ${ }^{42}$, in which the Environment domain was the one that influenced the most a lower perception of QoL.

Regarding the study design, all intervention studies showed an increase in QoL after the intervention. The studies that showed the best results were those that performed bone marrow cell transplantation ${ }^{28,29}$. Despite presenting similar interventions, the methodological quality and the sample size differ. The study of Vilas Boas et al. ${ }^{28}$ was a clinical phase 1 trial, open, uncontrolled and conducted with 28 participants. The second study with stem cells was randomized and triple blind, performed with 234 participants ${ }^{29}$. Despite the points presented in the study by Vilas Boas, it was a pioneer report of great relevance for new perspectives in the treatment of $\mathrm{CD}$, as well as for larger studies to occur.

In this context, it is important to note that studies that carry out bone marrow cell transplantation are high cost researches that require good hospital infrastructure and trained staff. The intervention carried out by Mediano et al. ${ }^{30}$ required low financial resources, and an increase in QoL scores was observed. In this sense, when planning interventions that will be implemented in the service, it is important that they are viable, because, according to the Brazilian Consensus on $\mathrm{CD}$, infected individuals are more vulnerable and have less access to the health service network ${ }^{4}$. Thus, further cost-effectiveness studies are needed in order to clarify the clinical and economic feasibility for incorporating these interventions into clinical practice. It is known that research in this area can contribute to the organization and provision of health care 
and the implementation of actions and clinical strategies that influence all domains of $\mathrm{QoL}$ in patients with $\mathrm{CD}^{42,43}$.

As for the observational design studies, these showed methodological weaknesses and small sample size, and the studies with smaller sample sizes had 21 and 32 participants $\mathrm{s}^{40,33}$. The observational study with the largest sample size was the one with 361 participants ${ }^{11}$. Studies with small sample sizes make it difficult to generalize the results.

Regarding methodological weaknesses, the absence of inclusion and exclusion criteria for participants was identified, and some studies did not show how the sample size was determined ${ }^{26,34,35,39}$. Despite these points, observational studies have shown similar results; the Environment domain was the most fragile domain for QoL in people with $\mathrm{CD}$. This finding is of great importance for the planning of actions focused on this domain, considering that it presents issues related to social determinants of health observed in neglected diseases such as CD. For Siboni et al. ${ }^{44}$ financial support programs should be among the main priorities of the QoL improvement programs.

In relation to the profile of the studies, it was observed that investigations that include patients with $\mathrm{CD}$ in the chronic phase, presenting with digestive manifestations are not common in the literature, as only two studies enrolled participants with digestive manifestations ${ }^{11,25}$. This lack of evidence of the QoL in patients with this clinical profile explains that there is a need for further investigations in order to organize the health service aiming at improving care and, consequently, the QoL of these people. The lack of studies in patients with digestive manifestations may be related to the under diagnosis of this form of $\mathrm{CD}$. Another justification that is worth considering is the prevalence of the digestive form, which is lower than the cardiac manifestation $(<10 \%)^{4}$, and this presents more serious reported complications and may influence the greater interest in investigations that assess the impact on $\mathrm{QoL}^{45}$. Due to the scarcity of research, it is also not possible to know which clinical form of CD has the lowest QoL.

As for the QoL instruments, it is known that there is no specific instrument for $\mathrm{CD}$. Thus, the present work found four different types of instruments. Since the most used was MLWHFQ, this may be related to the fact that it is a specific instrument to assess QoL in patients with $\mathrm{HF}$, and most of the articles included were in patients with Chagas cardiomyopathy and $\mathrm{HF}^{19}$. This also justifies the use of KCCQ in one of the studies ${ }^{22}$. A cohort study used the two instruments, MLWHFQ and KCCQ, to assess the predictive capacity of HF. The KCCQ was better to predict death, transplantation, and hospitalizations of patients. This assessment can be valuable in clinical practice for the monitoring of patients and to evaluate their prognosis ${ }^{46}$.
The other two instruments that were used, SF-36 and WHOQoL-BREF are generic and can be used regardless of the disease or health condition. Analyzing the four different instruments, MLWHFQ, KCCQ, SF-36, and WHOQoL-BREF enabled us to determine the most suitable to assess the subjective perception of people with $\mathrm{CD}$ in a way that allows comparisons with other populations, and the best in this category was the WHOQoL-BREF. Thus, the MLWHFQ and KCCQ instruments are specific for people with HF, i.e., not all patients with $\mathrm{CD}$ have this morbidity. For the SF-36, despite being a generic instrument, its domains assess QoL only related to health. WHOQoL-BREF on the other hand, is an instrument that evaluates QoL in any situation including the ones not only related to health, and is free and widely used.

In addition to the different instruments used to assess QoL, it is important to note that the participants in the selected studies had different CD morbidities in addition to other comorbidities. This fact can influence the $\mathrm{QoL}$ result of the participants. It is known that even patients with the same disease at similar stages can be differently evaluated with regard to their symptoms and limitations ${ }^{47}$. For example, in some of the studies included in this review, the participants had HF, and they know that morbidity in its advanced state causes greater dysfunction, and consequently worse $\mathrm{QoL}^{48}$.

The articles included in this review present some points that prevented a more accurate assessment of QoL in patients with CD: the articles did not assess all the domains described in the instruments; and the use of four different instruments hindered a grouped analysis of the different domains assessed.

Despite the limitations presented, the investigation has important findings to assist in health planning, and consequently making it possible to improve the QoL of patients with $\mathrm{CD}$ : the need for investments in more robust studies that will assess the cost-effectiveness of interventions that improve QoL; the need for studies with $\mathrm{CD}$ individuals with digestive manifestations or with the indeterminate form, as there is a lack of evidence of QoL in these patients; and the need to standardize the use of an instrument for assessing QoL considering the domains and summary measures proposed by each instrument.

\section{CONCLUSION}

From the findings of this review, it can be concluded that the QoL of people with CD is still a challenge, and there is no superiority between the instruments used, thus their application will depend on the goals of each research. It was observed that interventions in patients with $\mathrm{CD}$ are valid and have a positive impact on the QoL of individuals with this 
disease, and that the Environment domain has the lowest score for QoL. It is suggested that in investigations involving the QoL assessment, the instruments should be the ones used in the instrument's validation studies. This process will allow the comparison between investigations. Thus, the QoL profile in individuals with $\mathrm{CD}$ is more accurately identified, and these indicators can be important for organizing the care of patients with $\mathrm{CD}$ and consequently, positively impact the QoL.

\section{AUTHORS' CONTRIBUTIONS}

Conception and design or analysis and interpretation of data: NRB, NDQ, CCSA, CDLO and CSC; writing of the article or relevant critical review of intellectual content: NRB, NDQ, CDLO, ECS, ALPR and CSC.

\section{FUNDING}

The SAMI-TROP cohort study is supported by the National Institutes of Health-NIH (grant N ${ }^{\circ}$ 5U19AI098461). ALPR is supported in part by CNPq (310679/2016-8 and 465518/2014-1) and by FAPEMIG (PPM-00428-17 and RED-00081-16)

\section{REFERENCES}

1. Brasil. Ministério da Saúde. Secretaria de Vigilância em Saúde. Doença de Chagas aguda no Brasil: série histórica de 2000 a 2013. Bol Epidemiol. 2015;46:1-9.

2. World Health Organization. Chagas disease (also know as American trypanosomiasis). [cited 2021 May 12]. Available from: https://www.who.int/en/news-room/fact-sheets/detail/ chagas-disease-(american-trypanosomiasis)

3. Requena-Méndez A, Aldasoro E, de Lazzari E, Sicuri E, Brown M, Moore DA, et al. Prevalence of Chagas disease in LatinAmerican migrants living in Europe: a systematic review and meta-analysis. PLoS Negl Trop Dis. 2015;9:e0003540.

4. Dias JC, Ramos Jr AN, Gontijo ED, Luquetti A, Shikanai-Yasuda MA, Coura JR, et al. II Consenso Brasileiro em Doença de Chagas, 2015. Epidemiol Serv Saude. 2015;25:7-86.

5. Sabino EC, Ribeiro AL, Salemi VM, Di Lorenzo Oliveira C, Antunes AP, Menezes MM, et al. Ten-year incidence of Chagas cardiomyopathy among asymptomatic Trypanosoma cruziseropositive former blood donors. Circulation. 2013;127:110515.

6. Silveira AC. Os novos desafios e perspectivas futuras do controle. Rev Soc Bras Med Trop. 2011;44:122-4.

7. Rassi Jr A, Rassi A, Marcondes de Rezende J. American Trypanosomiasis (Chagas Disease). Infect Dis Clin North Am. 2012;26:275-91.
8. Bern C. Chagas' disease. N Engl J Med. 2015;373:456-66.

9. Rassi Jr A, Rassi A, Marin-Neto JA. Chagas disease. Lancet. 2010;375:1388-402.

10. Sousa GR, Costa HS, Souza AC, Nunes MC, Lima MM, Rocha MO. Health-related quality of life in patients with Chagas disease: a review of the evidence. Rev Soc Bras Med Trop. 2015;48:121-8.

11. Santos-Filho JC, Vieira MC, Xavier IG, Maciel ER, Rodrigues Junior LF, Curvo EO, et al. Quality of life and associated factors in patients with chronic Chagas disease. Trop Med Int Health. 2018;23;1213-22.

12. Sprangers MA, de Regt EB, Andries F, van Agt HM, Bijl RV, de Boer $\mathrm{JB}$, et al. Which chronic conditions are associated with better or poorer quality of life? J Clin Epidemiol. 2000;53:895-907.

13. Kaplan RM, Frosch DL. Decision making in medicine and health care. Annu Rev Clin Psychol. 2005;1:525-56.

14. Ferreira AM, Sabino EC, Oliveira LC, Oliveira CL, Cardoso CS, Ribeiro AL, et al. Impact of the social context on the prognosis of Chagas disease patients: multilevel analysis of a Brazilian cohort. PLoS Negl Trop Dis. 2020;14:e0008399.

15. Cavalcanti MA, Nascimento EG, Alchieri JC, Andrade CM. Manifestações e estratégias de enfrentamento da Doença de Chagas que interferem na qualidade de vida do indivíduo: uma revisão sistemática. Cien Saude Coletiva. 2019;24:1405-16.

16. The WHOQOL Group. The World Health Organization Quality of Life Assessment (WHOQOL): position paper from the World Health Organization. Soc Sci Med. 1995;41:1403-9

17. Moher D, Liberati A, Tetzlaff J, Altman DG. Preferred reporting items for systematic reviews and meta- analyses: the PRISMA statement. Ann Intern Med. 2009;151:264-9.

18. Ouzzani M. Hammady H, Fredorowicz Z, Elmagarmid A . Rayyan-a web and mobile app for systematic reviews. Syst Rev. 2016;5:210.

19. Carvalho VO, Guimarães GV, Carrara D, Bacal F, Bocchi EA. Validation of the Portuguese version of the Minnesota Living with Heart Failure Questionnaire. Arq Bras Cardiol. 2009;93:39-44.

20. Ware JE Jr, Sherbourne CD. The MOS 36-item short-form health survey (SF-36). I. conceptual framework and item selection. Med Care. 1992;30:473-83.

21. Fleck MP. O instrumento de avaliação de qualidade de vida da Organização Mundial da Saúde (WHOQOL-100): características e perspectivas. Cien Saude Coletiva. 2000;5:33-8.

22. Green CP, Porter CB, Bresnahan DR, Spertus JA. Development and evaluation of the Kansas City Cardiomyopathy Questionnaire: a new health status measure for heart failure. J Am Coll Cardiol. 2000;35:1245-55.

23. Downs SH, Black N. The feasibility of creating a checklist for the assessment of the methodological quality both of randomised and non-randomised studies of health care interventions. J Epidemiol Community Health.1998;52:377-84. 
24. University of Oxford. Centre for Evidence-Based Medicine. [cited 2021 May 12]. Available from: https://www.cebm.net/

25. Ozaki Y, Guariento ME, Almeida EA. Quality of life and depressive symptoms in Chagas disease patients. Qual Life Res. 2011;20:133-8.

26. Oliveira BG, Abreu MN, Abreu CD, Rocha MO, Ribeiro AL. Health-related quality of life in patients with Chagas disease. Rev Soc Bras Med Trop. 2011;44:150-6.

27. Chambela MC, Mediano MF, Ferreira RR, Japiassú AM, Waghabi MC, Silva GM, et al. Correlation of 6-min walk test with left ventricular function and quality of life in heart failure due to Chagas disease. Trop Med Intern Health. 2017;22:1314-21.

28. Vilas-Boas F, Feitosa GS, Soares MB, Pinho-Filho JA, Mota AC, Almeida AJ, et al. Bone marrow cell transplantation in Chagas' disease heart failure: report of the first human experience. Arq Bras Cardiol. 2011;96:325-31.

29. Santos RR, Rassi S, Feitosa G, Grecco OT, Rassi Jr A, Cunha $\mathrm{AB}$, et al. Cell therapy in Chagas cardiomyopathy (Chagas Arm of the Multicenter Randomized Trial of Cell Therapy in Cardiopathies Study). Circulation. 2012;125:2454-61.

30. Mediano MF, Mendes FS, Pinto VL, Silva GM, Silva PS, Carneiro FM, et al. Cardiac rehabilitation program in patients with Chagas heart failure: a single-arm pilot study. Rev Soc Bras Med Trop. 2016;49:319-28.

31. Dourado KC, Bestetti RB, Cardinalli-Neto A, Cordeiro JA. Evaluation of the six-minute walk test in patients with chronic heart failure associated with Chagas' disease and systemic arterial hypertension. Rev Soc Bras Med Trop. 2010;43:405-8

32. Ritt LE, Carvalho AC, Feitosa GS, Pinho-Filho JA, Macedo CR, Vilas-Boas F, et al. Puntuación Heart Failure Survival Score en pacientes con enfermedad de Chagas: correlación con variables funcionales. Rev Esp Cardiol. 2012;65:538-43.

33. Vieira FC, Marinho PE, Brandão DC, Barbosa e Silva O Respiratory muscle strength, the six-minute walk test and quality of life in Chagas cardiomyopathy. Physiother Res Int. 2014:19:8-15.

34. Costa HS, Lima MM, Figueiredo PH, Chaves AT, Nunes MC, Rocha MO. The prognostic value of health-related quality of life in patients with Chagas heart disease. Qual Life Res. 2019;28:67-72

35. Pelegrino VM, Dantas RA, Ciol MA, Clark AM, Rossi LA, Simões MV. Health-related quality of life in Brazilian outpatients with Chagas and non-Chagas cardiomyopathy. Heart Lung. 2011;40:e25-31.

36. Lima MM, Rocha MO, Nunes MC, Sousa L, Costa HS, Alencar $\mathrm{MC}$, et al. A randomized trial of the effects of exercise training in Chagas cardiomyopathy. Eur J Heart Fail. 2010;12:866-73.
37. Botoni FA, Poole-Wilson PA, Ribeiro AL, Okonko DO, Oliveira BM, Pinto AS, et al. A randomized trial of carvedilol after renin-angiotensin system inhibition in chronic Chagas cardiomyopathy. Am Heart J. 2007;153:544.e1-8.

38. Teno LA, Costa R, Martinelli Filho M, Castilho FC, Ruiz I. Upgrading from VVI to DDD pacing mode during elective replacement of pulse generator. A comparative clinicalfunctional analysis. Arq Bras Cardiol. 2007;88:128-33.

39. Gontijo ED, Guimarães TN, Magnani C, Paixão GM, Dupin S, Paixão LM. Qualidade de vida dos portadores de doença de Chagas. Rev Med Minas Gerais. 2009;19:281-5.

40. Souza AC, Rocha MO, Teixeira AL, Júnior JO, Sousa LA, Nunes MC. Depressive symptoms and disability in chagasic stroke patients: Impact on functionality and quality of life. J Neurol Sci. 2013;324:34-7.

41. Shen L, Ramires F, Martinez F, Bodanese LC, Echeverría LE, Gómez EA, et al. Contemporary characteristics and outcomes in chagasic heart failure compared with other nonischemic and ischemic cardiomyopathy. Circ Heart Fail. 2017;10:e004361.

42. Quintino ND, Sabino EC, Silva JL, Ribeiro AL, Ferreira AM, Davi GL, et al. Factors associated with quality of life in patients with Chagas disease: SaMi-Trop Project. PLoS Negl Trop Dis. 2020;14:e008144.

43. Ghiasi B, Sarokhani D, Dehkordi AH, Sayehmiri K, Heidari MH, et al. Quality of life of patients with chronic kidney disease in Iran: systematic review and meta-analysis. Indian J Palliat Care. 2018;24:104-11.

44. Siboni FS, Alimoradi Z, Atashi V, Alipour M, Khatooni M. Quality of life in different chronic diseases and its related factors. Int J Prev Med. 2019;10:65.

45. Nunes MC, Beaton A, Acquatella H, Bern C, Bolger AF, Echeverría LE. Chagas cardiomyopathy: an update of current clinical knowledge and management. Circulation. 2018;138:e169-209.

46. Yee D, Novak E, Platts A, Nassif ME, LaRue SJ, Vader JM. Comparison of the Kansas City Cardiomyopathy Questionnaire and Minnesota Living With Heart Failure Questionnaire in predicting heart failure outcomes. Am J Cardiol. 2019;123:80712.

47. Faria VS, Matos LN, Trotte LA, Rey HC, Guimarães TC. Association between quality of life and prognosis of candidate patients for heart transplantation: a cross-sectional study. Rev Latino-Am Enfermagem. 2018;26:e3054.

48. Yancy CW, Jessup M, Bozkurt B, Butler J, Casey DE, Drazner MH, et al. 2013 ACCF/AHA Guideline for the Management of Heart Failure: a report of the American College of Cardiology Foundation/American Heart Association Task Force on Practice Guidelines. Circulation. 2013;128:e240-327. 